\title{
JANUARY-FEBRUARY 1987
}

TWENTY-SEVENTH YEAR - No. 256

\section{international review of the red cross}

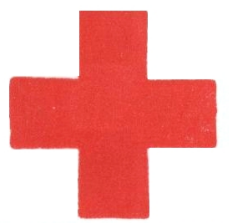

INTER ARMA CARITAS

GENEVA

INTERNATIONAL COMMITTEE OF THE RED CROSS FOUNDED IN 1863 


\title{
INTERNATIONAL COMMITTEE OF THE RED CROSS
}

Mr. ALEXANDRE HAY, Honorary doctorates from the Universities of Geneva and St. Gallen, Lawyer, former Director-General of the Swiss National Bank, President (member since 1975)

Mrs. DENISE BINDSCHEDLER-ROBERT, Doctor of Laws, Honorary Professor at the Graduate Institute of International Studies, Geneva, Judge at the European Court of Human Rights, Vice-President (1967)

Mr. MAURICE AUBERT, Doctor of Laws, Vice-President (1979)

Mr. JACQUES F. DE ROUGEMONT, Doctor of Medicine (1967)

Mr. ULRICH MIDDENDORP, Doctor of Medicine, head of surgical department of the Cantonal Hospital, Winterthur (1973)

Mr. HENRY HUGUENIN, Banker (1974)

Mr. RICHARD PESTALOZZI, Doctor of Laws, former Vice-President of the ICRC (1977)

Mr. ATHOS GALLINO, Doctor of Medicine, Mayor of Bellinzona (1977)

Mr. ROBERT KOHLER, Master of Economics (1977)

Mr. RUDOLF JÄCKLI, Doctor of Sciences (1979)

Mr. DIETRICH SCHINDLER, Doctor of Laws, Professor at the University of Zürich (19611973; 1980)

Mr. HANS HAUG, Doctor of Laws, Honorary Professor at the St-Gall School of Advanced Economic and Social Studies, former President of the Swiss Red Cross (1983)

Mr. PETER ARBENZ, Bachelor of Political Science (1983), (on leave of absence since March 1986)

Mr. PIERRE KELLER, Doctor of Philosophy in International Relations (Yale), Banker (1984)

Mr. RAYMOND R. PROBST, Doctor of Laws, former Swiss Ambassador, former Secretary of State at the Federal Department of Foreign Affairs, Berne (1984)

Mr. ODILO GUNTERN, Doctor of Laws, former member of the Swiss Council of States (1985)

Mr. ANDRÉ GHELFI, former Central Secretary and Vice-President of the Swiss Federation of Metal Workers (1985)

Mrs. RENÉE GUISAN, General Secretary of the international "Institut de la Vie", member of the Swiss Pro Senectute Foundation, member of the International Association for Volunteer Effort (1986)

Mr. DANIEL FREI, Professor of Political Science, University of Zurich (1986)

Mr. ALAIN B. ROSSIER. Doctor of Medicine, former Professor for the rehabilitation of paraplegics at Harvard University, lecturer at the Medical Faculty of Geneva University, President of the International Medical Society of Paraglegia (1986)

Mr. CORNELIO SOMMARUGA, Doctor of Laws of Zurich University, Doctor h.c. rer.pol. of Fribourg University (Switzerland) (1986)

\section{EXECUTIVE COUNCIL}

\author{
Mr. ALEXANDRE HAY, président \\ Mr. MAURICE AUBERT \\ Mr. RICHARD PESTALOZZI \\ Mr. ATHOS GALLINO \\ Mr. RUDOLF JÄCKLI \\ Mr. PIERRE KELLER \\ Mr. ANDRÉ GHELFI
}

The International Committee of the Red Cross (ICRC), together with the League of the Red Cross and Red Crescent Societies and the 144 recognized National Red Cross and Red Crescent Societies, is one of the three components of the International Red Cross and Red Crescent Movement.

An independent humanitarian institution, the ICRC is the founding body of the Red Cross. As a neutral intermediary in case of armed conflicts or disturbances, it endeavours on its own initiative or on the basis of the Geneva Conventions to protect and assist the victims of international and civil wars and of internal troubles and tensions, thereby contributing to peace in the world. 


\section{MISCELLANEOUS}

\section{BOOKS AND REVIEWS}

Accession of the Argentine Republic to the Protocols .................. 108

Interpretative statements . . . . . . . . . . . . . 108

Republic of the Philippines: Accession to Protocol II

States parties to the Geneva Conventions of 12 August 1949 - States parties to the Protocols of 8 June 1977 (as at 31 December 1986) . . . . . . . . . . Resolution of the Organization of American States Resolution of the Forty-first Session of the General Assembly of the United Nations on the Protocols additional to the Geneva Conventions . . . . .

Commentary on the Additional Protocols of 8 June 1977 to the Geneva Conventions of 12 August 1949

Mirador - my term as Hitler's guest .......

Ces lieux où Henry Dunant... (Roger Durand/Michel Rouèche) . . . . . . . . . . . . . 123

Vews and Reviews ................ 125

Vew publications . . . . . . . . . . . . . . . 128

International Review of the Red Cross has been published, in French, under various titles, by the International Committee of the Red Cross (ICRC) since 1869. Its first complete edition in English was issued in 1961.

- As the official organ of the ICRC and the International Red Cross and Red Crescent Movement,

- specializing in international humanitarian law and ICRC doctrine,

- recording the international activities of the Red Cross, mainly for reference purpose, as a chronicle of events,

International Review of the Red Cross provides a constant flow of information and maintains the necessary link between the members of the International Red Cross and Red Crescent Movement.

EDITOR: Jacques Meurant, editor-in-chief

ADDREss: International Review of the Red Cross

17, avenue de la Paix

$\mathrm{CH}$ - 1202 - Geneva, Switzerland

SubSCRIPTIONS: one year, Sw. frs. 30.-; single copy Sw. frs. 5.-.

Postal Cheque Account: No. 12 - 1767 Geneva

Bank account No. 129.986 Swiss Bank Corporation, Geneva

The International Committee of the Red Cross assumes responsibility only for material over its own signature. 